\title{
Influence of Competitive Advantage Strategy for Business Success
}

\author{
Anny Nurbasari \\ Fakultas Ekonomi \\ Universitas Kristen Maranatha \\ Bandung, Indonesia, \\ annurbas_61@yahoo.co.id
}

\author{
Nisa Hanum Harani \\ Politeknik Pos Indonesia \\ Bandung, Indonesia \\ nisaharani@gmail.com
}

\begin{abstract}
The strategy is a very important tool for achieving a competitive advantage, to face the competition by creating product diversification and competitiveness. The purpose of this study was to examine the effect of competitive advantage in terms of low cost and differentiation to business success, as well as test variable combination of competitive advantages (low cost and differentiation of products) to business success Kartika Sari. Analysis to test the hypothesis, the which uses Multiple Linear Regression Analysis. The results showed that the application of the differentiation strategy has a significant impact on the success of Kartika sari. But the application of competitive advantage strategies Low Cost no effect on business success, as well as the application of competitive advantage strategy combination of Low Cost and differentiation has no effect on business success or performance of the Company. The decision makers of companies, especially in the culinary industry in the application of competitive advantage generic strategies need to focus on a strategy for sustainable competitive differentiation in the creative industry in general.
\end{abstract}

Keywords- business success, competitive advantage, differentiation, low cost

\section{INTRODUCTION}

The impact of the development of business and market opportunities to make creative industries more widely. The competition will increasingly steer the company towards market positioning culinary industry to constantly develop and capture market share. These conditions resulted in the company is required to always create competitive advantage businesses to survive in the market on an ongoing basis by providing a product or service quality and excellent service to customers, which is always evolving and changing so that consumers are loyal, not least culinary business Kartika Sari , patisserie which a trade mark or icon of Bandung.

Need a strategy to compete in this creative industry, because of the success of the culinary industry in market share can not be separated from business strategy plan that has been and will be implemented by each offender culinary industry. For the culinary industry, strategies generic strategies can be used as a reference for dealing culinary competition among industry players amid the dynamics of changes in consumer tastes and a variety of another creative industry is emerging as a competitor. According [1] basic purpose of strategic management is to create a competitive advantage as the most important condition for business success. All potential of the company aimed to achieve this goal with the daily operational decisions based on the long-term strategy.

According [2] the company's strategy broadly classified into three levels, namely corporate level strategy, strategic business level and functional level strategies. Corporate-level strategy with regard to the selection of domain, scope vertically, horizontally, and market linkages with the level of integration between the different businesses. Business level strategy with regard to domain selection, how companies compete effectively in an industry [3]. Functional level strategies focused on maximizing the productivity of resources in any particular function and is generally derived from the business strategy [4].

Application of generic strategies according to Porter's still relevant in the competitive industry. There are three generic strategies are cost leadership (cost leadership), differentiation and focus. The focus strategy has two variants, the focus on cost or differentiation focus on a particular segment. According to Porter generic strategy is to seek power to compete in an industry that is profitable. Competitive strategy aims to build a profitable and sustainable position against the forces that determine the competitive industry. Therefore in order to win the competition of creative industries need to have a generic strategy is clear and precise in order to have a better performance in the face of increasingly fierce competition. Implementation of business-level strategy is essential in an increasingly competitive anticipating competition. According [5] there are two basic types of competitive advantage a company can have is a low cost strategy (cost leadership) and differentiation strategy. The significance of any strengths or weaknesses of a company is ultimately a function of the relative cost or differentiation.

From the results of previous studies, there is a gap that is according to research [6] as well as [7] indicated positive overall generic strategy and significantly improve the performance of the company. According to research [8], the company gives emphasis to both strategies are cost leadership and differentiation strategies are classified into groups of integrated strategies. [9] stated that the company is implementing an integrated strategy has a lower performance 
compared to the cost leadership strategy and differentiation strategy.

This study fills some of the gaps with a focus on creative industries, especially the culinary industry. The reason the development of the research is to bridge the gap small and medium enterprises in developing its business strategy in terms of competitive advantage that is constituted by: Efforts to empower SMEs is becoming increasingly critical associated with changes in the global business environment dramatically, so that SMEs are required to achieve a competitive advantage and were able to maintain existence [10]. Meanwhile, it was realized the competitiveness of SMEs in Indonesia are still relatively low and are vulnerable to changes in the business environment that are increasingly turbulent and uncertain. This condition affects the resulting low productivity and not least SMEs experienced a business [11]. This is because SMEs are less able to adapt and be responsive to the business environment faced due to lack of internal capacity owned [12]. In addition, customers who are very intelligent, dramatic changes in technology, the rise of many competitors offer similar products and more innovative and more different with more competitive prices. This phenomenon is a challenge SMEs, to find a business strategy that is relevant in terms of competitive advantage which is expected to have an impact on its business success.

This study will provide some important contributions to fill the gap by identifying how much influence the competitive advantage in terms of lower costs and product differentiation to business success, as well as test variable combination of competitive advantages (low cost and differentiation of products) to business success. This will broaden understanding of the competitive advantage for SMEs. The empirical findings of this study are expected to be valuable information for improving the success of the SMEs, which is based on previous empirical findings are quite diverse, from research [13]; [14];[15]; [16]; research [17]; [18]; [19].

\section{EFFect Of Competitive Advantage Of Low Cost And DIFFERENTIATION TO BUSINESS SUCCESS}

In general, small businesses Medium has limitations in controlling strategic resources, as well as the level of market research and formal planning is still relatively low. These conditions encourage the importance of investment to develop strategic resources in line with the implementation of strategies in order to create competitive advantage and results in improved corporate performance [20]. [21] suggested that a competitive advantage can be gained from strategic resources created or acquired, maintained and developed by the company as a base the selection of competitive strategy, so that later could act as "strategic weapon" to maneuver to face market competition.

Thus, the success of SMEs in enhancing the business success is not only derived from the mastery, control, and development of strategic resources, but the application of competitive strategy according to strategic resources, is able to give an edge to compete, to succeed better business in the long term , Resource-based view to formulating some fundamental differences needed to understand the process of creating a competitive advantage SMEs better. The general distinction is made between resources and competence. Resources owned SMEs are all physical, human, and financial assets that contribute in different ways in the process of production output input. These resources utilized, in part or in whole, thus enabling the development of a number of knowledge and capabilities that generate competence.

Competitive advantage in view [5] can mean having a low cost, differentiation advantage, or focus on successful strategies. Porter believes that the competitive advantage grows fundamentally from the company's value can be created for buyers who exceed the cost of creating it. Value is what a buyer is willing to pay, and superior value derived from bid prices lower than competitors for equivalent benefits or providing unique benefits that more than offset a higher price.

Meanwhile, [22] defines as a competitive advantage over normal reception sustainable. [23] states that competitive advantage can appear on the company when their actions in the industries or markets create economic value and when a bit of the company's competitors to do the same.

According to [24], the notion of competitive advantage is an edge over competitors gained by delivering greater customer value, through lower prices or by providing more benefits that correspond with higher pricing. Some of the indicators used to measure competitive advantage is unique, rare, not easily imitated, not easily replaced, and competitively priced. [25] Stated that a competitive advantage is a collection of strategies to determine the benefits of a company from the competition between other companies. The competitive strategy includes low cost and differentiation. Furthermore, the combination of both strategies is called the focus. Basically every company competing in an industry environment has a desire to be more superior than its competitors. Competitive advantage is the relative advantage of an organization that may exceed its competitors.

Competitive advantage is basically growing from a value or benefit that the company could be created for the customer. If the company is able to create excellence through one of the three generic strategies proposed by Porter, it will obtain competitive advantage [21]. [26] States that competitive advantages are the kinds of strategies to help the company maintain its viability. The opinion was supported by [27] which states that in a competitive market, the company's ability to produce the performance, especially the financial performance, highly dependent on the degree of competitive advantage.

The success of the business is also affected by the company's specific position in the occupied industrial environments. Companies operating in the same industry may decide to adopt a different strategy, in the analysis of competitive strategy (competitive strategy also called Porter's Five Forces) of a company, Michael A. Porter introduces three types of generic strategies, which can be selected are: 1. Cost leadership, when the companies offering the same product at a lower price than its competitors. 2. Differentiation, when companies offer different products (higher quality and more functions more) at a higher price. In this case, the company 
must set prices at a level sufficient to cover the higher costs in producing differentiation. If this is not done, the differentiation strategy will lead to high costs that are not covered by the company's revenue.

In a differentiation strategy, the main focus is to distinguish between products of the business unit by creating something unique for the customer (customer). 3. Focus, when companies follow one of two strategies before, but focusing on a limited segment of the market. We will have the focus on cost when the company decides to pursue cost leadership in a limited market segment and focus differentiation when it acts in accordance with the differentiation strategy.

From the research [7]; [6] generic strategy indicates overall positive and significant impact on company performance , [9] stated that the company is implementing an integrated strategy has a lower performance compared to the cost leadership strategy and differentiation strategy. According to research [8], the Company gives emphasis to both strategies are cost leadership and differentiation strategy, both generic strategies are classified into groups of integrated strategies. [14] conducted a study on the bank with the conclusion that the bank is implementing more than one strategy is superior to implement the strategy, while [28] state differentiator has a much stronger market than the cost leadership and has a positive influence on the success of business or corporate performance.

The success of the business or the company's performance by [29] is a successful company in terms of new products, as measured through the development of new products, and market development, growth share as measured through sales growth and market share, profitability measured by operating profits, profit to sales ratio, cash flow operation, return on investment, return on assets, and the product quality. Empirical support has been shown by many researchers in the use of indicators of performance of small companies[30], [31] sales growth rate, employment growth, return on assets (ROA), market share profitability, and size as an indicator in measuring the company's performance. The success of the business or the company's performance in this study was measured using the size of the sales growth, revenue growth, market share changes, and the position of competitors. The measurement scale for the fulfillment of the objectives and the relative competitive performance adapted from [18].

They then develop a hypothesis:

H1: low- cost strategies affects the success of the business.

H2: Differential strategy affect the success of the business.

H3: Strategies combination of low cost and differentiation affect the success of the business.

\section{RESEARCH METHOD}

The study population was Kartika sari businesses in which the owner and employees are considered to know and be able to analyze industry environment influenced by considering strategies for the establishment of low cost and differentiation. The sampling technique using saturation sampling where all members of the population used as a sample. Methods of data collection using questionnaires, interviews, and observations. Measurement of the validity of using the confirmatory factor analysis (CFA), Test reliability was calculated using Cronbach Alpha. Analysis to test the hypothesis of the influence of competitive advantages (low cost and differentiation), and combinations thereof to business success, the which uses Multiple Linear Regression Analysis. This type of research is done in this paper is to use descriptive research and verification. In this study, quantitative analysis of data used is Likert scale, on a five (5) from a one-point (1) - Strongly to five (5) - Strongly Agree.

Furthermore, the selected indicators to measure strategy competitive advantage in this research refers to research [17] and[18], and has been adapted where indicators of differentiation is its emphasis on new products or products that are available in order to serve customers better well, the uniqueness of the product, the quality of products, the introduction of new products into the market, the number of new products offered, the intensity of the promotion, development of the sales force and the development of the brand strong, while indicators of cost leadership is the emphasis on efficiency costs, cost reduction, efficiency of operational, sales capacity, competence prices and general cost control. The success of the business or the company's performance in this study was measured using the size of the sales growth, revenue growth, market share changes, and the position of competitors.

\section{FINDINGS AND DISCUSSIONS}

Testing of the study instrument is conducted by looking at the Validity Test, and the Reliability Test.

The measurement of quantitative validity uses Confirmatory Factor Analysis (CFA), performed by using SPSS 11 software for Windows. The results are as follows: it can be concluded that the level of intercorrelation between variables already qualified and factor analysis can be continued as the value of KMO generated amounts to 0.769 with 0.001 significant level $(\leq 0.05)$.

Based on the Rotated Component Matrix, it can be concluded that indicators of competitive advantages (low cost strategy of X1 and differentiation X2) and the combination of low cost and differentiation strategies (X3) as well as that indicator of business success (Y) is valid.

Reliability test results with test Cronbach alpha $(\alpha)$ in this study indicate that all variables of the study are reliable, since the entire value of the alpha coefficient of each study variable is greater than the standardized (0.6), so that each item on the question measurement instruments can be used.

The coefficient of determination on the model summary, showed that the value of Adjusted R Square of 0.663. This shows that the percentage contribution that independent variable influence competitive advantage (Low Cost, Differentiation) and a combination of Low Cost and Differentiation on the dependent variable Enterprises business success or performance of $66.3 \%$ the remaining $33.7 \%$ influenced by other factors not included in the model this research. 
Simultaneous significance test (Test F) shows that the significant value indicates a yield of $0,040(<0,05)$ so it can be concluded that the independent variable Competitive advantage (Low Cost, Differentiation), and combination strategies with the same effect on business success or Performance Company.

Partial regression coefficient test ( $t$ test) This test is used to determine whether the independent variables in the regression model X (Low Cost; Differentiation; Combination of Low Cost and differentiation) is partially significant effect on the variable Business Success (Y).

From the results of multiple regression analysis output can be presented as follows, shows table 1 .

Significance Tests Effect of Partial (Test T), shows that the dimensions of the Low Cost showed insignificant value of 0.633 for $>0.05$; Differentiation dimension shows significant value of 0.03; and the combination of dimensions Low Cost and Differentiation showed insignificant value 0.372 for $>0.05$.

\section{Equation of Regression Line}

Multiple regression equations between Competitive advantage (Low- Cost and Differentiation) and combination strategies to Business Success which produce: $Y=\mathbf{3 9 , 0}-\mathbf{0 , 5 7}$ $X 1+0,368 X 2+0,825 X 3$

TABLE I. RESUlTS OF MULTIPLE LINEAR REGRESSION ANALYSIS

\begin{tabular}{|c|c|c|c|c|c|}
\hline \multirow[b]{3}{*}{ Model } & \multicolumn{4}{|c|}{ Coefficients $^{\mathrm{a}}$} & \multirow[b]{3}{*}{ Sig. } \\
\hline & \multicolumn{2}{|c|}{$\begin{array}{l}\text { Unstandardized } \\
\text { Coefficients }\end{array}$} & \multirow{2}{*}{\begin{tabular}{|c|}
$\begin{array}{c}\text { Standardized } \\
\text { Coefficients }\end{array}$ \\
Beta
\end{tabular}} & \multirow[b]{2}{*}{$\mathbf{t}$} & \\
\hline & $\boldsymbol{B}$ & $\begin{array}{l}\text { Std. } \\
\text { Error }\end{array}$ & & & \\
\hline \begin{tabular}{l|l}
1 & (Constant)
\end{tabular} & 39.0 & 26.168 & & 1.6187 & .131 \\
\hline Low Cost & -0.462 & .078 & -0.57 & -4.37 & .633 \\
\hline Differentiation & .173 & .048 & .368 & 3.165 & .003 \\
\hline $\begin{array}{l}\text { Low Cost and } \\
\text { differentiation }\end{array}$ & .706 & .737 & .825 & .827 & .372 \\
\hline $\begin{array}{l}\text { a. Dependent } \\
\text { Business Success }\end{array}$ & Variable: & & & & \\
\hline
\end{tabular}

\section{Interpretation Results Analysis}

From the analysis that has been done has proved there is the influence of variables Competitive advantage (Low Cost, Differentiation) and combination strategies to Business Success.

Coefficient Determination Adjusted R Square value is equal to 0.663. This calls shows Competitive advantages variation of independent variables (Low Cost, Differentiation) and combination strategies used in the model is able to explain the variation of $66.3 \%$ Business Success dependent variable. While the remaining $33.7 \%$ influenced or explained by other variables not included in this research model.

The degree of influence and magnitude described by the parameters of influence, $b$, of magnitude 39.0. This figure implies that increasing Competitive advantage (Low Cost,
Differentiation) and combination strategies by $1 \%$ can be expected to affect the business success rise by $39 \%$.

Effect of Competitive advantage (Low Cost) to Business Success

Testing individually, showed there is a significant influence of the variables Competitive advantage (Low Cost and Differentiation) with the degree of influence and different magnitudes. Direction of the relationship and the magnitude of each effect can be explained as follows: Effect of changes in Competitive advantage (Low Cost) to negative for Business Success (-0.57), Which means that with the addition of $1 \%$ in Competitive advantage (Low Cost) will be followed by a decline in business success by $57 \%$ if other variables remain presupposed; And conversely, if the Competitive advantage (Low Cost) can be saved by $1 \%$, then the increase in business success increased $57 \%$. Competitive advantage (Low- Cost) partially have no significant relationship with the variable business success and $\mathrm{H} 1$ rejected.

The argument can be explained as follows Competitive advantage (Low- Cost) consists of six (6) indicator is the cost efficiency of production, finding ways to reduce costs, operational efficiency, optimizing sales capacity, offering competitive prices, and general cost control. Low Cost strategy (cost leadership) emphasis on producing standard products (equal in every aspect) with the cost per unit is very low. This product (goods and services) are usually aimed at consumers who are relatively easily influenced by a shift in the price (price sensitive), or using price as a determining factor purchase decision. In terms of customer behavior, a strategy of this type is in accordance with the needs of customers who are included in the category of conduct lowinvolvement, when consumers are not (too) care about the differences between different brands, (relative) does not require product differentiation, or if there are a large number of consumers have bargaining power bargain significant.

Mainly in the commodities markets, this strategy does not only enable the company to withstand the price competition going on but also can be a market leader (market leader) to determine prices and ensure market profit rate is high (above average) and through the ways-stable aggressive way in efficiency and cost effectiveness. Sources of cost effectiveness are varied. These include the utilization of economies of scale (economies of scale), investment in the best technology, sharing cost and knowledge in the internal organization, the impact of the learning curve and experience (learning and experience curve), capacity optimization utilities, and good access to raw materials or distribution channels. In principle, the main reason for the implementation of the strategy of upstream integration (backward integration), downstream (forward integration), as well as sideways (horizontal integration) is to obtain the benefits of this low-cost strategy. To be able to run a low-cost strategy, Kartikasari should be able to meet the requirements in two areas: resources (resources) and organizations. This strategy can only be run if it has several advantages in the field of corporate resources, namely: strong capital resources, skilled in process engineering (process engineering), close supervision, easily manufactured, 
as well as distribution and promotion costs low. While the field of organization, companies must have: the ability to control costs tightly, good control of information, incentives based on a target (results-based incentive allocations).

Effect of Competitive advantage (Differentiation) to Business Success

Effect of competitive advantage (Differentiation) the success of the business or the company's performance has a positive relationship amounted to $0.368 \%$, When other variables held constant, the figure is above implies that with increasing competitive advantage (Differentiation) by $1 \%$ will increase the success of the business or the company's performance by $36,8 \%$. Differentiation partially variable has a significant relationship with the variable success of the business or the company's performance so that $\mathrm{H} 2$ is acceptable. Differentiation is a generic strategy that emphasizes the advantages of product innovation to maintain customer loyalty. In this study consisted of six indicators, namely: Development of new products or products that are available, the introduction of new products into the market, the number of new products on offer, promotion, sales force development and efforts to build a strong brand. Product Differentiation Strategy (differentiation), prompting the company to be able to find unique in its target markets.

The uniqueness of the products (goods or services) put forward allows a company trying to attract maximum interest from potential customers. How differentiation of products vary from market to market, but due to the nature and the physical attributes of a product or experience the satisfaction of (real or psychological) are perceived by consumers from consuming the products offered. A variety of different variants of shape, taste, delicacy, hygienic, does not contain preservatives, packing and ease of maintenance, a flexibility of size, convenience to shopping, and various other things that are difficult to imitate opponents just a few examples of differentiation in the culinary field. This type of regular strategy targeted at potential customers who are relatively not put the price for making the decisions (price insensitive).

It should be noted that there are various levels of differentiation. Differentiation does not provide a guarantee of competitive advantage, especially if the products are standard in circulation has been (relatively) meet consumers' needs or if competitors are able to do a quick impersonation. Examples of using this strategy right is the product that is both durable goods (durable) and difficult to imitate by competitors. Another risk of this strategy is that if the difference or uniqueness of the product offered was not appreciated (considered normal) by consumers. If this is the case, then the competitor that offers standard products with low-cost strategy will be very easy to seize the market. Therefore, the differentiation strategy, intelligence Research and Development department is very important.

The study of SMEs Kartikasari shows differentiation strategy implementation an important influence on the success of the business or the company's performance. The empirical findings of this study support previous research conducted by[15], [16], [28] and [32] that the strategy of differentiation effect on the company's performance. The findings of this research shows that the differentiation variables significantly influence the variable success of the business or the company's performance. the average value differentiation strategy smallest average indicator is 3.90 , while 5 other indicators in the top four so the overall respondents rated well for the entire indicator variable of differentiation. the factor analysis of the indicators of differentiation strategy which has the highest weight is an indicator of the number 1 followed by the number $2,5,4,6$, and 3 so that implementation of the strategy of differentiation indicators that need attention is on the development of the diversity of innovation of new products with variants of new flavors and product availability in the market, sales force development, promotion and the rate of new product introduction to the market.

Effect of Combination Strategy Competitive advantage (Low Cost and Differentiation) to Business Success

Combination strategy is to combine elements of Competitive advantage (Low Cost and Differentiation). The indicator is the merger of the two strategies Competitive advantage Low Cost and Differentiation. The study of SMEs Kartika sari showed that the combination of strategy implementation does not significantly influence the success of the business or the company's performance. The results of this study support previous research conducted by [9]; [19] Of the average indicator value combination strategy under four (4) so that the overall respondents rated not good enough for the entire indicator variable combination strategies. Empirical findings support the hypothesis that the results of test results are not significant.

Combination strategy is a combination of two or more strategies are applied simultaneously. However, it should be noted that a combination of strategies must be operated very carefully because if too in bringing more complex risks. There is no company that can implement all strategies simultaneously despite all intended to provide a profit to the company. Therefore, amid the difficulty of the decision taken, the scale of good and proper priorities need to be built. This is needed because the resources owned company certainly has its limitations. Priority is needed, because the combination of strategy implementation will mean the deployment of resources and organizational capabilities that may be read by competitors, so they can take the steps that it is jeopardizing the company's position. In a highly diversified company, the strategy is often implemented as a combination of the divisions that exist to apply different strategies. Likewise, companies that are attempting to maintain its operations (struggle for survival) usually apply a combination strategies of some defensive strategies simultaneously.

\section{CONCLUSION AND SUGGESTIONS}

From this study it can be concluded that the application of the differentiation strategy has an influence which is essential to the success of SMEs Kartika sari, mainly for the following indicators: the development of products with new flavors, sales force development and promotion of the introduction of new products into the market. But the application of competitive advantage strategies Low Cost no effect on business success or performance of the Company, as 
well as the application of competitive advantage strategy combination of Low Cost and differentiation has no effect on business success or performance of the company.

Further research is needed in other industries to determine the effect of competitive advantage in a generic strategy, especially in sectors other creative industry as a comparison with the culinary industry. The decision makers of companies, especially in the culinary industry for the application of competitive advantage in the generic strategies need to focus on the strategy of differentiation in order to compete sustainably in the creative industries generally.

\section{REFERENCES}

[1] Tichá, I., Hron J.,2003. Strategické rízení. In: Credit, Praha, p235.

[2] Hax, A.C., Majluf, N.S. 1984. "The corporate strategic planningprocess", Interfaces, Vol. 14 No.1, pp.47-60.

[3] Hambrick, D.C. 1980. "Operationalising the concept of business-level strategy in research", Academy of

[4] Schendel, D.,\& Hofer, C.W. 1979. Strategic Management:A new View of Business Policy and Planning,,Little Brown, Boston, MA.

[5] Porter,. 1993. Keunggulan Bersaing, Menciptakan dan Mempertahankan Kinerja Unggul. Jakarta: Erlangga.

[6] Yasar, F. 2010. Competitive strategies and Firm Performance:Case Study on Carpeting Sector, Journal of Social Sciences Institute, Vol. 7, p. 309-324.

[7] Teeratansirikool, .,\& Shiengtai. 2011. Competitive strategy,performance measurement and organizational performance: empirical study in Thai listed companies Ph.D. at the School of Management, Asian Institute of Technology and a lecturer, Prince of Songkla University, Thailand.

[8] Kim, L., Lim, Y. 1988. "Environment generic strategies,and performance in rapidly developing country: a taxonomic approach", Academy of Management Journal, Vol. 31 No.4, pp.802-27.

[9] Nandakumar, A.G., Nicholas, O. 2011. "Generic strategiesand performance - evidence from manufacturing firms", International Journal of Productivity and Performance Management, Vol. 60 Iss: 3, pp.222-251.

[10] Anatan, L., \& L. Ellitan. 2009. Strategi Bersaing: Konsep, Riset, dan Instrumen. Alfabeta Bandung.

[11] Riyanti, B. P. D. 2003. Kewirausahaan dari Sudut Pandang Psikologi Kepribadian. Grasindo Jakarta.

[12] Scarborough, N. M.,\& T. W. Zimmerer. 2008. Essential of Entrepreneurship and Small Business Management. Prentice Hall International Inc. New Jersey.

[13] Kling, J.A., Smith, K.A. 1995. "Identifying strategic groupsin the US airline industry: an application of the Porter model", Transportation Journal, Vol. 35 No.2,pp.26-34.

[14] Chan, R.Y., \& Wong, Y.H. 1999. "Bank Generic Strategies: Does Porters Theory Apply in an International

[15] O'Farrell, P., Hitchens, D., and Moffat, L. 1992. "Does strategymatter? An analysis of generic strategies and performance in business service firms", Business Strategy Review, Vol. 3 No. 1, pp. 71-87.

[16] Marlin, D., Lamont, B.T.,\& Hoffman, J.J. 1994. "Choice situation, strategy, and performance: are-examination", Strategic Management Journal, Vol. 15, pp. 229-39.

[17] Dess, G.G., \& Davis, P.S. 1984. "Porter's 1980. Genericstrategies as determinants of strategicgroup membership and organizational performance", Academy of Management Journal,Vol. 27 No. 3, pp. $467-88$.

[18] Ramanujam, V., \& Venkatraman, N. 1987. "Planning system characteristics and planning effectiveness", Strategic Management Journal, Vol. 8 No. 5, pp. 453-68.
[19] Daly Rustamblin., Arman Thoyib., Djumilah Zain. 2013. Pengaruh Strategi Generik terhadap Kinerja Perusahaan, www. EJurnal.com/2013.

[20] Barney, J. B. 2001. Gaining and Sustaining Competitive Advantage. Addison Westley Reading. Mass.

[21] Aaker, David. 1989. Managing assets and skills: The key to a sustainable competitive advantage. California Management Review, Winter: $91-106$

[22] Peteraf, M.A. 1993. The Cornerstones of Competitive Advantage: A Resource-Based https://faculty.fuqua.duke.edu/ charlesw/s591/Bocconi Duke/Papers/C08/Peteraf_1993_SMJ.pdf

[23] Barney, J. B., G. Ray., \& W. A. Muhanna. 2004. Capabilities, Business Processes, and Competitive Advantage: Choosing the Dependent Variable in Empirical Tests of The Resource-Based View. Strategic Management Journal 25: 23-37.

[24] Kotler, Philip., \&Gary Armstrong. 2001. Prinsip-prinsip Pemasaran, Jilid 1, Edisi Kedelapan,Jakarta,Erlangga.

[25] J. David Hunger .,\& Thomas L. Wheelen, 2004. Strategic Management and Business Policy, 9th Edition, Pearson Prentice Hall.

[26] Day, G.S., \& R Wensley 1988. Assesing Advantage : A Framework for Diagnostic Competitive Superiority," Journal of Marketing, Vol 52, April, pp.1-20.

[27] Ferdinand, A. 2006. Metode Penelitian Manajemen: Pedoman Penelitian untuk Penulisan Skripsi, Tesis dan Disertasi Ilmu Manajemen. Edisi Kedua. Semarang. Badan Penerbit Universitas Dipo negoro.

[28] Kumar, K., Subramanian, R., Strandholm, K. 2002. "Marketorientation and performance: does organizational strategy matter?", Journal of Applied Business Research, Vol. 18 No.1, pp.37-50.

[29] Pelham, M. Alfred., David T. Wilson 1996. A Longitudinal Study of The Impact of Market Structure, Firm Structure, Strategy, and Market Orientation Culture on Dimenntions of Small Firms Performance, Journal of Academy of Marketing Science. 24, 1, pp. 27-43.

[30] Olson. D. Philip., Donald W. Bokor .1995. Strategy Process-Content interaction : Effect On Growth Performance In Small Firm. Journal of small Business Management, pp. 34-44.

[31] Hadjimonalis, Anthanasios ,2000. An Investig ion of Innovation Atecendent in Small Firms in the Contex of A Small Developing Country, Journal of R\&D Management, 30, 3, pp. 235-245.

[32] Koo, C.M., Koh, C.E., \& Nam, K. 2004. An examination of porters competitive strategies in electronic virtual markets: a comparison of two on-line businessmodels. InternationalJournal of Electronic Commerce, Vol. 9 No. 1, pp. 163-80.

[33] Atuahene-Gima, K., \& A. Ko. 2001. An Empirical Investigation of The Effect of Market Orientation and Entre-preneurship Orientation Alignment on Product Innovation. Organ Sci. 12(1): 54-74.

[34] Banking Center", International Business Review, Vol.8 Nos 5/6, pp. $561-90$.

[35] Hadjimonalis., Anthanasios., Keith Dickson. 2000. Innovation Strategies of SMEs in Cyprus, A Small Developing Country, International Small Business journal . 18,4, pp. 62-79.

[36] Management Review, Vol. 5 No.4, pp.567-75.

[37] Kumar, K., Subramanian, R., \& Strandholm, K. 2002. Market orientation and performance: does organizational strategy matter? Journal of Applied Business Research, Vol. 18 No. 1, pp. 37-50.

[38] Miles, R.E., Snow, C.C. 1978. "Organisational Strategy,Structure and Process". NewYork, NY: McGraw-Hill.

[39] Porter, M.E. 1980. "Competitive Strategy - Techniques forAnalysing Industries and Competitors". New York: NY: The Free Press.

[40] Porter, M.E. 1985. "Competitive Advantage: Creating and Sustaining Superior Performance", The Free Press 